\title{
Effect of Income Gap: Happiness, Cost and Midlife Crisis
}

\author{
WangLugang, HouXiaoli \\ sundsp@126.com
}

\begin{abstract}
Personal happiness, economic and social behavior and organizational behavior are widely concerned. New concepts and tools are defined such as ability income, expected income, expected difference, and income gap. With these new tools, this paper provides an in-depth analysis of common social and economic issues: statistics on the gap between rich and poor, midlife crisis, lifelong learning, layoff, happiness-income paradox, U-shaped curve of happiness, pension systems, seniority-wage system, and so on. The happiness does not depend on the actual income, but mainly depends on expected difference. Income gap increases the cost of the organization.
\end{abstract}

JEL classification: I31

Keywords: Expected income; Actual income; Ability income; Expected difference; Income gap

\section{Introduction}

The economics of happiness or happiness economics is the quantitative and theoretical study of happiness, positive and negative affect, well-being, quality of life, life satisfaction and related concepts, typically combining economics with other fields such as psychology and sociology.

Labor income is very important for most workers. About two-thirds of American national income is labor income including wages and benefits ${ }^{1}$.

This paper defines new concepts and tools such as ability income, expected income, expected difference, and income gap.

This paper uses the new tools to analyze the common social and economic phenomena: statistics of the gap between rich and poor, midlife crisis, lifelong learning, labor cost, Layoff, happiness-income paradox, pension system, U-shaped curve of happiness, Seniority-wage system, and so on. This paper also proposes improvements to a small number of issues.

\section{Definition of Gap Theory}

\subsection{Ability Income}

Ability income refers to the income that workers can earn with their work ability, under the premise of the labor market regulation.

$$
\mathrm{I}_{\mathrm{A}}=\mathrm{K}_{\mathrm{A}}(\mathrm{C}, \ldots) * \mathrm{~L} * \mathrm{~F}_{\mathrm{A}}(\mathrm{Y})
$$

Where $\mathrm{I}_{\mathrm{A}}$ represents ability income, $\mathrm{K}_{\mathrm{A}}$ represents a coefficient function, $\mathrm{C}$ represents the work characteristics, $\mathrm{L}$ represents the workload, $\mathrm{F}_{\mathrm{A}}$ represents an ability function, and $\mathrm{Y}$ represents the workers' age.

Ability income curve is shown in Fig. 1(The curve is fitted by logistic function): 


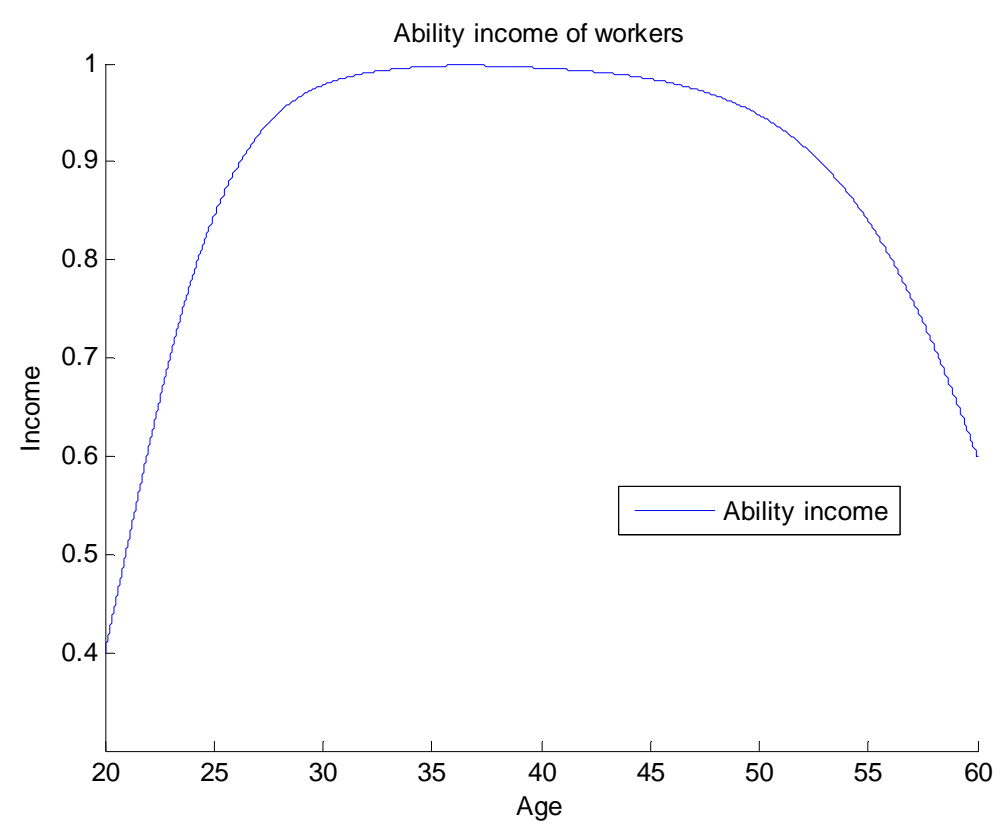

Fig. 1. Ability income curve

The main characteristics of ability income curve are:

- Ability income is regulated by the labor market.

- Ability income curve firstly increases and then decreases, which can be roughly divided into three stages: growth stage, stable stage, decline stage.

- Due to differences of the work characteristics and personal ability, ability income curve varies widely.

- If no effort is paid (i.e. $\mathrm{L}=0$ ), ability income is equal to zero.

The mechanism behind ability income curve:

Work ability mainly includes: physical strength, intelligence (including memory, etc.), and work experience (knowledge).

In general, physical strength reaches the peak before the age of 30 (the bone density is the highest about in 30 years old), and the memory reaches its peak at the age of 25 .

For some middle-aged people, they may pay more physical strength and intelligence into children or parents, instead of their job.

For most jobs, 10 years of work experience is enough, and more experience has little effect on work ability (marginal utility). As knowledge ages, sometimes the acceptance of new technologies is not as fast as that of young people.

The peak ages of ability income curves vary widely for different industry and position. For example, blue-collar workers with simple skills peak at about 30 years old, junior programmers peak at about 35 years old, senior managers in large companies need more work experience, and the dancers are youthful.

\subsection{Expected Income}

Expected income refers to the reasonably expected income of workers, under the premise of obtaining happiness and positive motivation.

$$
\mathrm{I}_{\mathrm{E}}=\mathrm{K}_{\mathrm{E}}(\mathrm{L}, \mathrm{P}, \ldots) * \mathrm{~F}_{\mathrm{E}}(\mathrm{Y})
$$


Where $I_{E}$ represents expected income, $K_{E}$ represents a coefficient function, $L$ represents the workload, P represents the income of the surrounding people, $\mathrm{F}_{\mathrm{E}}$ represents an expected function, and $\mathrm{Y}$ represents the age.

Expected income curve is shown in Fig. 2 (The curve is fitted by linear and logistic function):

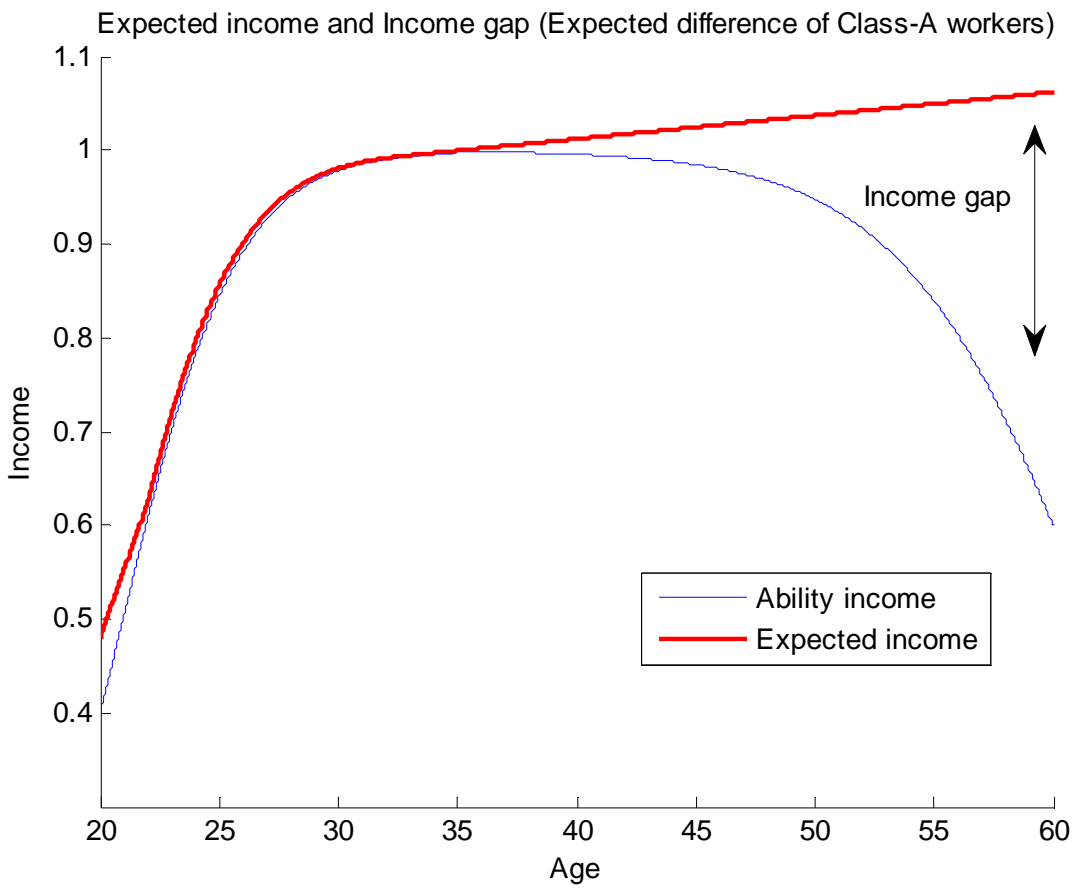

Fig. 2. Expected income and Income gap (Expected difference of Class-A workers)

The main characteristics of expected income curve are:

- Expected income curve is not fixed shape.

- In the working state, expected income curve is incremental, that is, the growth rate is greater than or equal to zero.

- In the passively unemployed state (layoff), expected income will be matched with ability income and then regrow in Fig. 3.

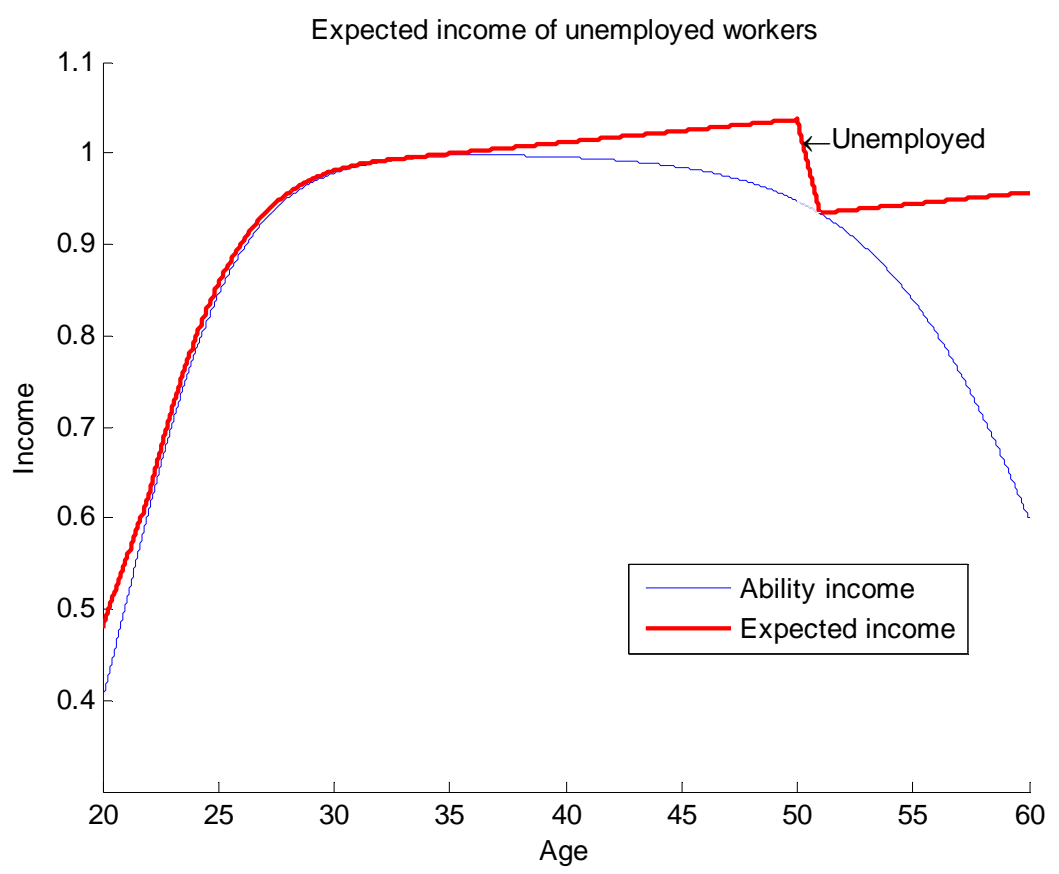


Fig. 3. Expected income curve of unemployed

The mechanism behind expected income curve:

Humans hate losses, and strongly dislike the sense of deprivation caused by income decline. The growth of expected income can better make workers feel happy and positive.

\subsection{Actual Income}

Actual (Real) income refers to actual income earned by the workers with their labor.

Actual income is represented by the symbol $\mathrm{I}_{\mathrm{R}}$.

Most workers are divided into two main types:

- Class-A workers

Class-A workers refer to workers in profit-oriented and private enterprise.

Their actual income is roughly equal to ability income.

Typical workers include workers in most competitive enterprises. Because of market regulation, actual income of individuals varies widely.

- Class-B workers

Class-B workers refer to workers in the nonprofit or state-own organization.

Their actual income is roughly equal to expected income.

Typical workers include workers in government, state-own schools, state-own hospitals, and some state-owned enterprises. Because it is not market regulation, actual income of individuals varies not as widely as that of class-A workers.

Although there are other types of workers, this paper only discusses the two main types.

Class-A workers are the mainstream in the capital society.

\subsection{Expected Difference}

The difference between expected income and actual income is defined as expected difference.

$\mathrm{I}_{\text {diff }}=\mathrm{I}_{\mathrm{E}}-\mathrm{I}_{\mathrm{R}}$

Where $I_{\text {diff }}$ represents expected difference, $I_{E}$ represents expected income, and $I_{R}$ represents actual income.

Expected difference of Class-A workers is shown in Fig. 2.

For Class-A workers, actual income is roughly equal to ability income, and the main characteristics of expected difference are:

- In youth, expected difference is about zero, and happiness and positive motivation are higher.

- As workers grow older, expected difference is getting larger, and the happiness and positive incentives are getting lower.

- In the short term, wage has certain stickiness. When ability income declines, actual income does not fall immediately, and there is a certain delay in expected difference. 
For Class-B workers, actual income is roughly equal to expected income, that is, expected difference is approximately equal to zero.

Happiness depends on the two comparisons. One comparison is between actual income and historical income, so the growth of expected income has positive motivation. The other comparison is between actual income and expected income, so expected difference is important.

For Class-A and Class-B workers, their expected difference is not the same.

\subsection{Income Gap}

The difference between expected income and ability income is defined as income gap (it is also called Wang's gap).

$\mathrm{I}_{\text {gap }}=\mathrm{I}_{\mathrm{E}}-\mathrm{I}_{\mathrm{A}}$

Where $\mathrm{I}_{\text {gap }}$ represents income gap, $\mathrm{I}_{\mathrm{E}}$ represents expected income, and $\mathrm{I}_{\mathrm{A}}$ represents ability income.

Income gap of workers is shown in Fig. 2.

Income gap is roughly equal to expected difference of Class-A workers, and ignores the wage stickiness.

The main characteristics of income gap are:

- In youth, income gap is about zero.

- As workers grow older, income gap becomes larger.

- For the Class-A and Class-B workers, income gap is the same which brings convenience for many analyses.

As workers grow older and income gap gets larger:

For Class-A workers, actual income is roughly equal to ability income. We can say that workers by themself have to burden income gap, which brings about happiness decline.

For Class-B workers, actual income is roughly equal to expected income. We can say that the organizations or the governments burden income gap, which brings about cost increase.

As workers grow older, income gap bring about different effect of for the two types of workers shown in Table 1.

\begin{tabular}{|c|c|c|c|}
\hline As workers grow older & Expected difference & Happiness and positive motivation & Who burden income gap \\
\hline Class-A workers & Get bigger & Lower & Individuals by themselves \\
\hline Class-B workers & Roughly equal to zero & Higher & Organizations or governments \\
\hline
\end{tabular}

Table 1. Effect of income gap

This paper will use these new tools to analyze on common social and economic phenomena. 


\section{Gap between Rich and Poor}

\subsection{Overestimated Gap between Rich and Poor}

The government annually counts income including labor income and other income, and assesses income distribution with the Gini coefficient and the income share of certain number population.

Actual income distribution of American households in 2006 is shown in Table 2.

The people will have this impression: highest fifth Households have $49.7 \%$ of income, lowest fifth Households only have $3.4 \%$ of income, and the gap between rich and poor is too large.

\begin{tabular}{|c|c|}
\hline $\begin{array}{c}\text { Income class of } \\
\text { households }\end{array}$ & $\begin{array}{c}\text { Total income received by } \\
\text { households in this class }\end{array}$ \\
\hline Lowest fifth & $3.4 \%$ \\
\hline Second fifth & $8.7 \%$ \\
\hline Third fifth & $14.8 \%$ \\
\hline Fourth fifth & $23.4 \%$ \\
\hline Highest fifth & $49.7 \%$ \\
\hline
\end{tabular}

TABLE 2. Distribution of money incomes of American households, 2006

The gap between rich and poor is overestimated, mainly because the annual income is used as the statistical source data.

- Ignore that ability income changes over time

Most workers are in competitive enterprise (Class-A workers), and ability income is equal to actual income. Ability income changes with age.

Take the Chinese blue-collar workers as an example. When a manual worker is 25 years old, he may work on the assembly line in an electronics factory, and he can earn $\$ 800$ monthly. When he is 60 years old, he may be a gatekeeper, and he can only earn \$200 monthly.

Using annual income, the blue-collar workers have four-fold difference. In fact, they belong to one class.

- Ignore the annual fluctuation in income

Annual fluctuation of income may also affect statistical results.

The Income in many jobs is fluctuant, such as dancers, performers, CEOs, and share traders.

Using annual income shown in Table 3, $\mathrm{X}$ and $\mathrm{Y}$ have four-fold difference. In fact, $\mathrm{X}$ and $\mathrm{Y}$ belong to one class.

\begin{tabular}{|c|c|c|c|c|}
\hline Year & 1 & 2 & 3 & 4 \\
\hline X Income (\$) & $8 \mathrm{~K}$ & $2 \mathrm{~K}$ & $8 \mathrm{~K}$ & $2 \mathrm{~K}$ \\
\hline Y Income (\$) & $2 \mathrm{~K}$ & $8 \mathrm{~K}$ & $2 \mathrm{~K}$ & $8 \mathrm{~K}$ \\
\hline
\end{tabular}

TABLE 3. Annual fluctuation

\subsection{Recommended Statistical Method}

The perfect statistical method does not exist.

This paper counts the income of workers in the same age and $\mathrm{N}$ years.

$\mathrm{I}_{\mathrm{N} \_ \text {age }}=\left(\mathrm{I}_{1}+\mathrm{I}_{2}+\ldots+\mathrm{I}_{\mathrm{N}}\right) / \mathrm{N}$

Where, $\mathrm{I}_{\mathrm{N} \_ \text {age }}$ is the income in the same age and $\mathrm{N}$ years, $\mathrm{I}_{1}$ is the income of the first year, $\mathrm{I}_{2}$ is the income of the second year, $\mathrm{I}_{\mathrm{N}}$ is the income of the Nth year.

If $\mathrm{N}$ is large enough, consider the weights of different years, such as interest rates.

$$
\mathrm{I}_{\mathrm{N} \_ \text {age }}=\left(\mathrm{I}_{1} * \mathrm{r}_{1} * \mathrm{r}_{2} * \ldots * \mathrm{r}_{\mathrm{N} \_1}+\mathrm{I}_{2} * \mathrm{r}_{2} * \ldots * \mathrm{r}_{\mathrm{N} \_1}+\ldots+\mathrm{I}_{\mathrm{N}}\right) / \mathrm{N}
$$


Where $r_{1}$ is the interest rate of the first year, $r_{2}$ is the interest rate of the second year, and $r_{N_{-} 1}$ is the interest rate of the $N-1$ year.

For example, the government can get $\mathrm{I}_{10 \_40}(\mathrm{~N}=10$ and age=40) in the 40-year-old people, and then use the Gini coefficient to measure the gap between rich and poor.

If the value of $\mathrm{N}$ is too large, it is slow to respond to changes in income. If the value is too small, it is susceptible to annual fluctuation.

The government can choose different $\mathrm{N}$ and age and their combinations as the published statistics.

\section{Youths with High Unemployment Rate and Education}

Young people have a high unemployment rate, after they graduate from school.

The minimum-wage Laws are generally considered to be one of the main reasons.

Here we give another equivalent explanation.

The students' ability does not match the demand without practical work experience. Ability income of students is very low, and the company burdens the cost of training. Expected income of some students is not lower than the legal minimum-wage.

Income gap is a relatively large shown in Fig. 2.

Because many companies are not willing to burden income gap of students, unemployment rate is high.

It is difficult to completely solve the high unemployment rate of young people. For example, lowering the legal minimum-wage can reduce the unemployment rate, but it is often difficult to achieve politically.

Here is another suggestion. The school can reduce the time spent on textbook knowledge, increase the internship time in the company, improve the work ability of students (i.e. ability income), and ultimately reduce income gap of graduate.

\section{Midlife Crisis and Juniorization}

\subsection{Midlife Crisis}

The midlife crisis is a transition of comfortlessness and unhappiness that can occur in mid-aged individuals, typically 35-55 years old.

It is generally believed that there are many causes of the midlife crisis: the decline of physical health, the burden of supporting the elderly and raising children, unrealizable desires, and so on. This paper tries to give a new explanation.

As workers enter middle age, and income gap gets larger:

- For Class-A workers:

In the short term, due to the stickiness of income, actual income will not drop immediately, and the company will burden income gap. However, as income gap is getting larger, the mid-aged workers are getting more anxious that their cost performance is getting lower.

In the long term, when income gap is large enough, some companies are reluctant to burden the cost caused by income gap 
and some mid-aged workers will be passively unemployed. In the passively unemployed state, expected income will be matched with ability income, which brings with workers a long period of anxiety and adaptation.

In a competitive society, the pressure is indeed high.

- For Class-B workers:

Income gap is burdened by the organizations and governments, and their midlife crisis is not as obvious as Class-A workers'.

With longer life-span, the retirement will be delayed. Income gap will be larger, and the midlife crisis will become more serious.

\subsection{Juniorization, Layoff and Gap Unemployment}

Staffs are young in many companies such as IT. Most reports are positive that young workers have taken the lead.

Where do older workers go? This is a good question.

There are always ups and downs in the enterprise. In the economic downturn, many companies lay off employees with large income gap who are older and newly graduated employees. This is an open secret about layoff. Some companies directly cut off grassroots employees over the age of 40 .

A new word "Juniorization" is Invented recently in Wall Street.

Unemployment is a serious social and economic problem. There are various reasons including jobs search, minimum-wage laws, unions, and efficiency wages. When income gap is very large, some mid-aged workers are unemployed. It is a new unemployment model, which is called gap unemployment.

In China, a very vivid word "blank-window period" is used to describe the time of unemployment.

If mid-aged workers are passively unemployed, there is often a long blank-window period of adaptation to reduce expected income.

\subsection{Lifelong Learning}

It is very difficult to completely solve the midlife crisis. One method often mentioned is lifelong learning.

Lifelong learning is popular and based on two main points: past knowledge is aging and knowledge is updated quickly in modern society.

We estimate that lifelong learning can play a role. It cans lengthen stable stage of ability income curve, but it cannot eliminate the midlife crisis. Lifelong learning can enhance the work experience (knowledge), but it cannot stop the physical strength and intelligence from decline.

Everyone will die inevitably, but he will not fear it everyday. One clearly understands that many people (though not everyone) will experience a midlife crisis because of income gap, and it will allay the fear of midlife crisis.

\subsection{Happiness-income Paradox}

Easterlin proposes the happiness-income paradox (Easterlin Paradox) ${ }^{2}$ : In the long term, happiness does not increase as a country's income rises ${ }^{3}$, and there is no significant difference in happiness between poor and rich countries.

Various theories have been advanced to explain the paradox, but don't reach a consensus. 
This paper tries to give a new explanation.

The happiness does not depend on the actual income, but mainly depends on expected difference.

In the long term, ability income is what workers should get in the labor market. If economic growth leads to income growth, it is not too happy thing that actual income equals ability income.

On the contrary, if expected income is high and actual income is low, it is rather sad that expected difference is large.

In the short term, if economic recovery leads that actual income is higher than expected income (expected difference is minus), workers will be happier.

\section{Pension System and U-shaped Curve of Happiness}

\subsection{Pension System}

Most countries in the world have adopted the pay-as-you-go pension system to ensure that old people are raised.

The fundraising is mainly from contributions of working people and transfers of government revenue.

When Class-A workers approach retirement age, ability income is very low. But once they retire, they do not need to work. At this time, ability income is instantaneously equal to zero, and the government pays pension. Pension increases annually in line with expected income.

At this point, income gap has changed shown in Fig. 4. Actual income of retirees is roughly equal to expected income.

Because actual income is much higher than ability income, the government burdens huge income gap. In addition, the government provides medical security for retirees.

With the aging of the population, income gap is larger, and the burden of the government is heavier. The government revenue ultimately comes from companies and working people, and income gap increase their costs.

A large income gap can even inhibit the fertility intentions of workers, which in turn accelerates the aging of the population.

The above problem is difficult to solve for a public opinion society. 


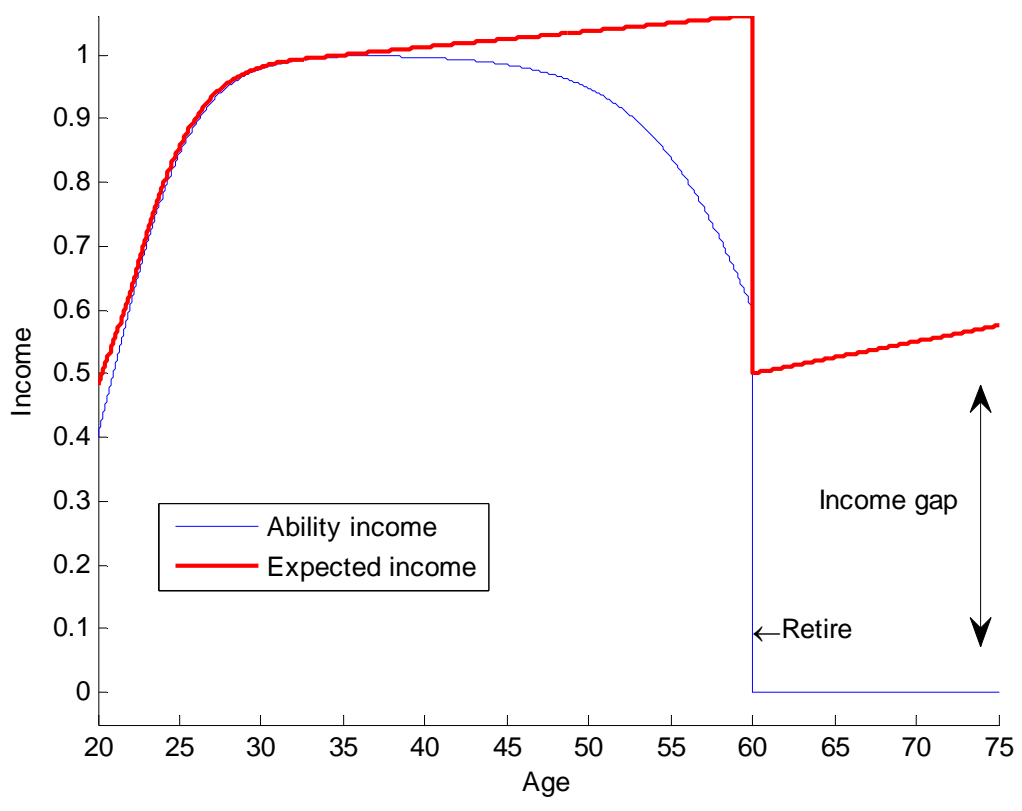

Fig. 4: Income gap of retiree with pension

\subsection{U-shaped Curve of Happiness}

Blanchflower and Oswald released the famous U-shaped curve ${ }^{4}$ of happiness shown in the Fig. 5. Happiness declines to the minimum in the middle age, and rises gradually in the old age.

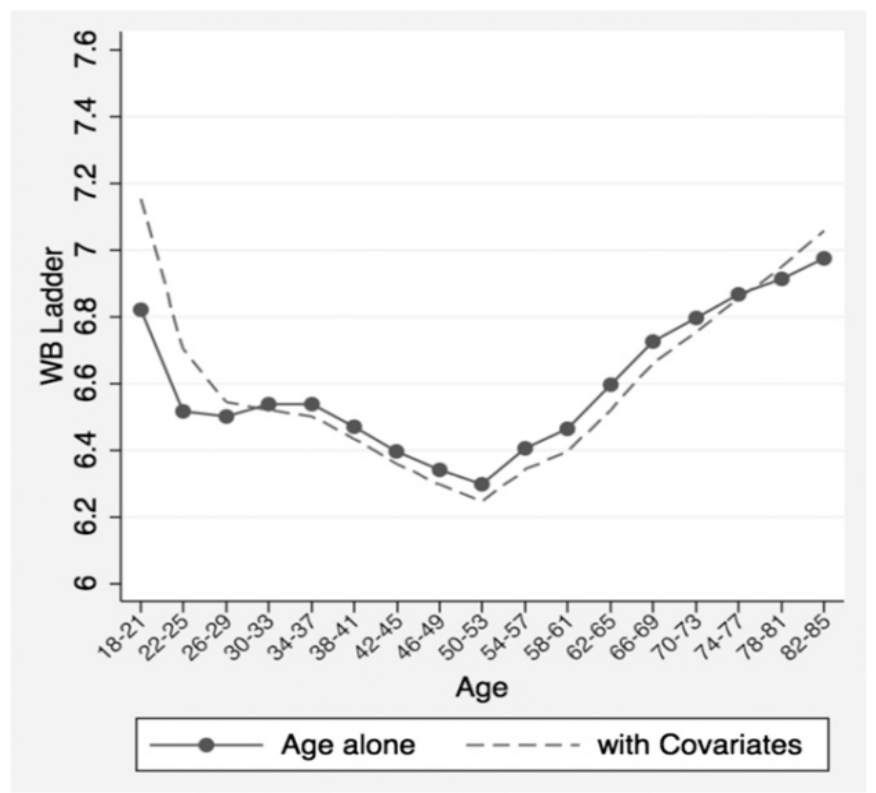

Fig. 5: U-shaped curve of happiness (Global Wellbeing (WB) ladder)

Various theories have been advanced to explain the U-shaped curve such as the elderly become more open-minded.

This paper tries to give a new explanation. Expected difference is close to zero with the increase of expected income and actual income in Fig. 4. Income gap of retirees is burdened by working people and the government. The retirees become enhanced Class-B workers. The retirees can get $40-80 \%$ income of working people without labor.

In the young age, income gap is close to zero. In the middle age, income gap is burdened by themself (midlife crisis) for 
Class-A workers. In the old age, income gap is burdened by working people and the government. This better explains the U-shaped curve of happiness.

Money is not everything. But happiness is often based on the growth of expected income and actual income, when expected difference is equal to zero.

\subsection{No Pension System}

If there is no pension system, there is no retirement.

Before 2000, Chinese society was an urban-rural structure, and there were huge differences between urban and rural residents. Retirees in cities have pension and medical insurance, and the peasants can only raise themselves without pension.

When the peasant grows older, their physical strength declines seriously. The peasants' ability income is very low and their actual income matches their ability income. The government does not burden income gap, and the peasants' children burdens income gap.

The old peasants often have the disease and mental stress such as powerless feeling and the burden of the children. At this time, their happiness is relatively low.

The suicide rate of the rural elderly in China is four times that of the urban elderly ${ }^{5}$. The mental stress caused by expected difference is one of the reasons. Of course, suicide is extremely rare with very complex factors.

After 2000, with the implementation of medical insurance and pension insurance in rural China, the suicide rate drops dramatically to the low level of the world.

\subsection{Who Burdens Income Gap of Retirees and Unfairness}

In 1982, the elderly population in China over 65 years old accounted for $4.9 \%$ of the total population. In 2017, the elderly population accounted for $11.4 \%$ with the rapid growth of economy6.

The pension system reflects humanity and social progress.

The pension's fundraising is mainly from contributions of working people and transfers of government revenue.

But China has its specialties.

In China, a worker pay pension by $8 \%$ of his income, the company pay pension by $20 \%$ of his income, and the total pension is $28 \%$ of his income. The pension is kept by the city (not county). If a worker pays pension with a total of 15 years, he can get pension after retirement.

Many people make a living in big city from small city for a few years and can not stay in one city for 15 years. For example, a worker makes a living in big city for 5 years, and returns to work in small city for 10 years. When the worker retires, he can get pension in small city. However, according to the existing rules, big city transfers only $20 \%$ of his pension to small city.

Small city burdens income gap of retiree, but big city takes away part of his pension. This is a bit unfair that the rich rob the poor. 


\section{Japanese Seniority-wage System and Labor Cost}

\subsection{Introduction of Seniority-wage System}

The lifelong employment system and seniority-wage system are the management models that were once popular in Japan.

The lifelong employment system encourages staff to work only in one company for life.

The seniority-wage system is that the company increases the wage of workers every year.

Proponents believe that they have many advantages. For example, employees are loyal to the company, the team is stable, the short-sighted things will not be done, and the company is willing to train workers.

Opponents believe that they have many disadvantages. For example, young workers are difficult to be promoted, and work ability is ignored.

\subsection{Labor Cost and Economic Recession}

For young workers, actual income is equal to ability income. At this time, income gap is equal to zero.

As workers grow older, income gap is larger and burdened by Japanese companies.

During the rapid economic growth in the 1960s-1970s, as long as many young employees were newly recruited or employed, the burden of the company was small. The problem can be ignored.

However, workers grow older and the country has entered the era of population aging. Income gap is larger and the burden of companies is heavier.

In the past two decades, the Japanese Economic recession continues. The previous explanations were mostly attributed to the bubble burst in the stock market and the property market in the 1990s. In the context of global economic growth, the bubble burst has such a long-term impact, which is rare and incomprehensible in the history of the world economy.

This paper tries to give a new explanation. The Japanese companies burden income gap, which bring about an increase of labor cost. Japanese Economy is export-oriented, and companies lose their competitive advantage in the increasing global competition.

The lifelong employment system and the seniority-wage system face enormous challenges, and most companies have abandoned them. The Japanese economy has begun to regrow again.

\section{Conclusion}

This paper defines new concepts and tools such as ability income, expected income, expected difference, and income gap. This paper uses the new tools to analyze the common social and economic phenomena: statistics of the gap between rich and poor, midlife crisis, lifelong learning, labor cost, layoff, pension system, U-shaped curve of happiness, seniority-wage system, and so on.

Because of limit of the paper, some applications are ignored. For example, as Mr. ChaoHe pointed out, banks need to assess people's ability income when lending. 
Someone will provide solutions to solve the others' problems. For example, the market mechanism will solve customer problems (demands) more efficiently by allowing producers to make a profit; pension system balances some inequities. Perhaps by certain means, some social or economic problems caused by income gap will be solved.

This paper focuses on workers whose income is base on labor, and not based on the assets. Because Fitzgerald told Hemingway: The rich are different from us.

\section{References}

1. Paul A Samuelson, William D Nordhaus , 2009. Economics. McGraw-Hill Education.

2. RICHARD A.EASTERLIN, 1974. Does Economic Growth Improve the Human Lot? Some Empirical Evidence. Nations and Households in Economic Growth, Pages 89-125. http://dx.doi.org/10.1016/B978-0-12-205050-3.50008-7.

3. Richard A. Easterlin1, Laura Angelescu McVey, Malgorzata Switek, Onnicha Sawangfa, and Jacqueline Smith Zweig, 2010. The happiness-income paradox revisited. PNAS December 28, 107 (52) 22463-22468.

4. David G. Blanchflower, Andrew J. Oswald, 2008. Is well-being U-shaped over the life cycle? Social Science \& Medicine 66 $1733 \mathrm{e} 1749$.

5. Michael R Phillips, Xianyun Li, Yanping Zhang, 2002. Suicide rates in China, 1995-99. Lancet; 359: 835-40.

6. 2018. China Statistical Yearbook. http://www.stats.gov.cn. 
Manuscript should be easy to quickly review whether it is suitable for publication, so a catalogue is added.

1. Introduction

2. Definition of Gap Theory ……1-

2.1 Ability Income

2.2 Expected Income

2.3 Actual Income

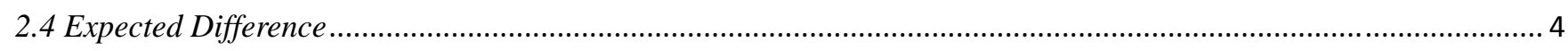

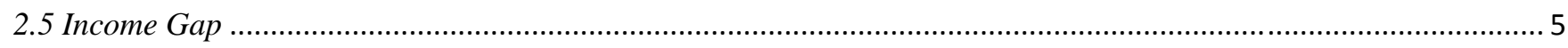

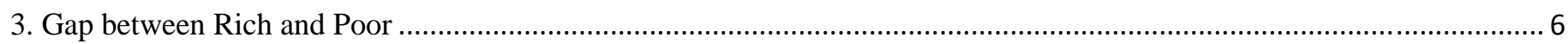

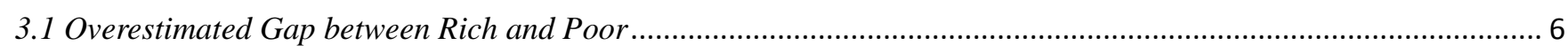

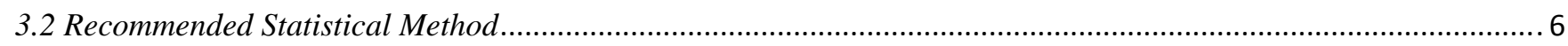

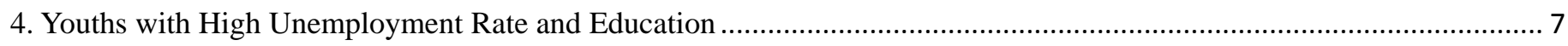

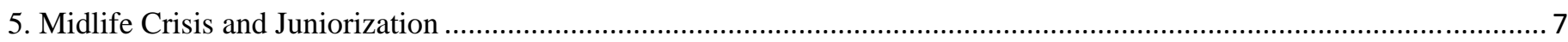

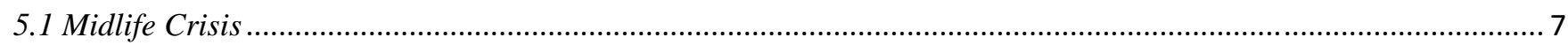

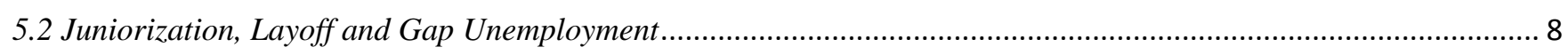

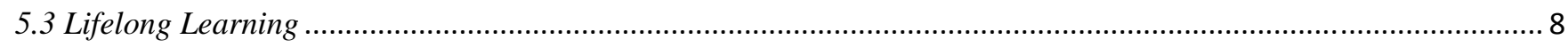

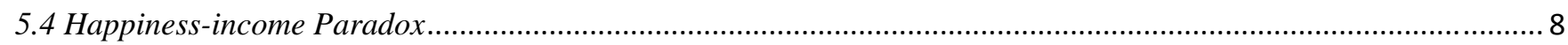

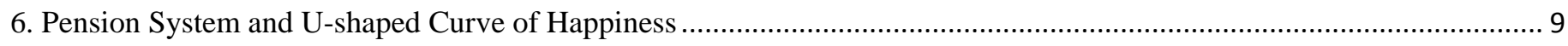

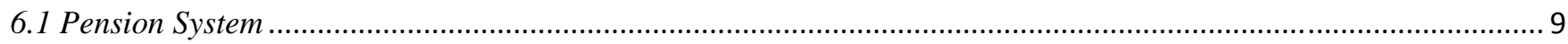

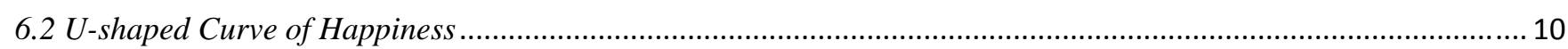

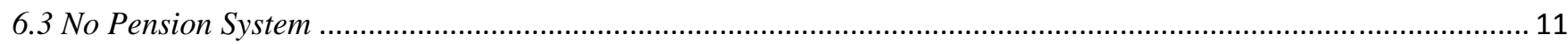

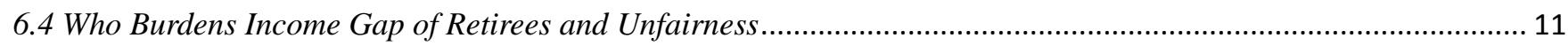

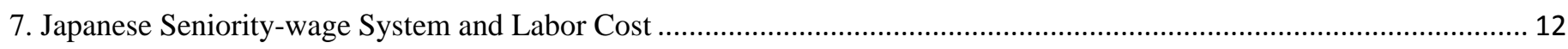

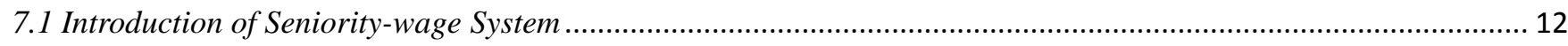

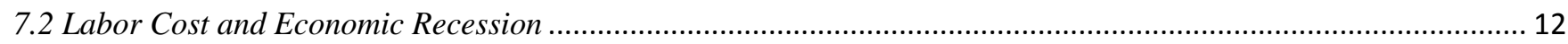

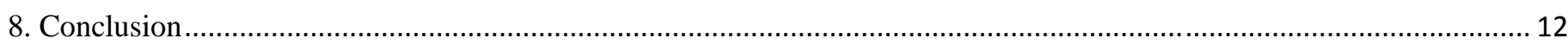

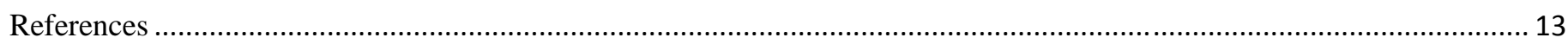

